\title{
Training in developing higher-order thinking based online test instrument for biology teachers in Sekayu City
}

\author{
Yenny Anwar ${ }^{\mathrm{a}, 1,{ }^{*}}$, Adeng Selamet ${ }^{\mathrm{a}, 2}$, Siti Huzaifah ${ }^{\mathrm{a}, 3}$, Kodri Madang $^{\mathrm{a}, 4}$ \\ ${ }^{a}$ Department of Biology Education, Faculty of Teacher Training and Education, Universitas Sriwijaya, Jl. Raya Palembang Prabumulih, KM. 32 \\ Inderalaya - Ogan Ilir, South Sumatera 30662, Indonesia

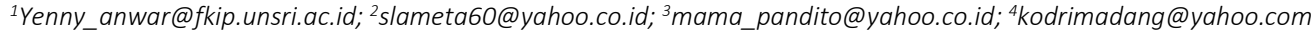 \\ * Corresponding author
}

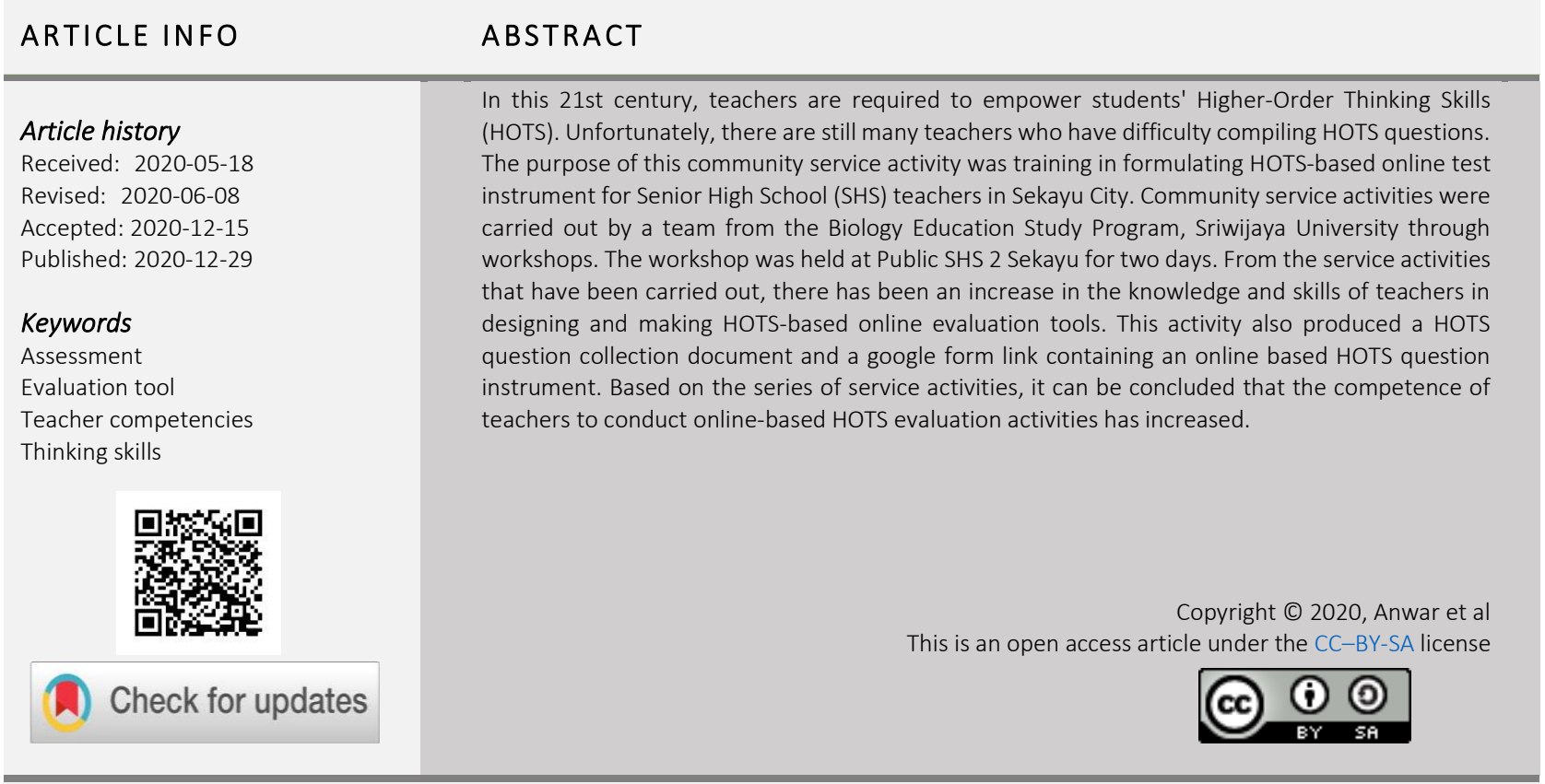

How to cite: Anwar, Y., Selamet, A., Huzaifah, S., \& Madang, K. (2020). Training in developing higher-order thinking based online test instrument for biology teachers in Sekayu City. Journal of Community Service and Empowerment, 1(3), 150-155. https://doi.org/10.22219/jcse. v1i3.12241

\section{PENDAHULUAN}

Keterampilan berpikir tingkat tinggi (Higher-order thinking skills/HOTS) termasuk kompentensi utama yang harus dikuasai seseorang di Abad 21 (Greiff et al., 2015; Saavedra \& Opfer, 2012). Dengan HOTS, seseorang dapat beradaptasi dengan tingginya laju informasi seperti saat ini. HOTS juga menjadi menjadi tumpuan bagi seseorang untuk bersaing di dunia kerja serta melihat peluang secara kritis (Dwyer et al., 2014; Miri et al., 2007; Mulnix, 2012). Mereka juga dapat melihat segala persoalan dari berbagai sudut pandang sehingga dapat memecahkan permasalahan menjadi lebih efisien (BeharHorenstein \& Niu, 2011; Montag-Smit \& Maertz, 2017).

Mengingat pentingnya HOTS, proses pendidikan dan pembelajaran harus diarahkan untuk memfasilitasi siswa menguasai kompetensi ini (Saavedra \& Opfer, 2012). Guru sebagai salah satu komponen utama proses pembelajaran harus mampu mendesain pembelajaran yang mampu memberdayakan HOTS siswa. Seiring dengan tuntutan tersebut, guru juga harus mampu merancang serta menyelenggarakan kegiatan evaluasi yang mampu mengakses HOTS para siswa (Ramdiah et al., 2019). Pasalnya, tujuan dan kegiatan belajar dalam proses pembelajaran harus sejalan dengan kegiatan evaluasi yang dilakukan.

Selain mampu menyelenggarakan kegiatan penilaian dengan baik, guru juga harus mampu mengikuti perkembangan teknologi (McKnight et al., 2016; Ottenbreit-Leftwich et al., 2010, 2012). Berkaitan dengan era digital saat ini, guru diharapkan mampu mendesain kegiatan penilaian berbasis dalam jaringan (daring) (Baran et al., 2011). Penilaian berbasis daring dianggap sebagai alat yang lebih praktis dan efisien karena guru akan lebih mudah mengakses, menilai dan 
meminimalkan kecurangan (Alruwais et al., 2018). Penilaian berbasis daring ini juga akan lebih menghemat biaya dan waktu karena tidak lagi menggunakan banyak kertas. Guru juga dapat langsung memperoleh hasil sesaat setelah siswa mengisi jawaban (Frankl \& Bitter, 2012).

Sayangnya, berdasarkan hasil wawancara terhadap guru-guru SMA di Kota Sekayu, dapat dinyatakan bahwa soal-soal yang disusun guru umumnya berupa pilihan ganda dan masih mengukur kemampuan tingkat rendah. Temuan ini sejalan dengan hasil penelahaan terhadap beberapa dokumen soal yang telah disusun guru. Hal ini dapat dimaklumi karena soalsoal tersebut kebanyakan berasal dari buku-buku pelajaran yang umumnya berupa diberikan soal-soal evaluasi yang kurang menuntut peserta didik banyak berpikir. Dari hasil wawancara dengan beberapa guru, dapat diketahui bahwa para guru masih belum begitu paham menentukan perilaku yang diukur serta kesulitan dalam merumuskan masalah yang dijadikan dasar pertanyaan. Di lain pihak, dari hasil wawancara juga terungkap bahwa mereka belum pernah dilatih secara khusus mengembangkan soal-soal yang kemampuan berpikir tingkat tinggi berbasis daring. Temuan lapangan ini sejalan dengan berbagai temuan penelitian yang menginformasikan bahwa banyak guru yang masih kesulitan mendesain proses (Retnawati et al., 2018) dan evaluasi pembelajaran berbasis HOTS (Andromeda et al., 2020; Epinasti et al., 2013; Ramdiah et al., 2019). Sejalan dengan kondisi tersebut, berdasarkan hasil rekomendasi ketua MGMP bahwa guru-guru Biologi di kota Sekayu masih membutuhkan pemahaman tentang alat evaluasi yang tepat untuk megukur HOTS siswa.

Pembaharuan dan perbaikan pendidikan seyogyanya diawali dari usaha meningkatkan mutu guru sebagai tenaga profesional. Salah satu kompetensi yang harus dikuasai guru profesional adalah mampu melaksanakan penilaian yang inovatif. Penilaian yang dikehendaki sebagai bagian dari penguatan proses harus mencakup pengukuran terhadap HOTS siswa. Oleh karena itu, bertolak dari hasil identifikasi permasalahan perlunya dilakukan upaya- upaya strategis, terencana, dan terprogram untuk mengatasi permasalahan tersebut. Salah satu langkah yang bisa ditempuh di antaranya melalui pendekatan strategis dengan menerapkan cara-cara yang terarah, terprogram, sesuai dengan kebutuhan di lapangan. Berpijak kepada kebutuhan tersebut, dalam rangka menjembatani dan menjadi solusi untuk mengatasai permasalahan yang dihadapi guru- guru Biologi di Kota Sekayu, kegiatan pengabdian masyarakat berupa kegiatan workshop penyusunan instrumen soal HOTS perlu dilakukan. Solusi ini sejalan dengan beberapa laporan terdahulu yang melaporkan bahwa kegiatan workshop berkontribusi dalam meningkatkan kompentesi guru (Anif et al., 2019; Irmawati et al., 2017; Mantra et al., 2019; Purwoko et al., 2017; Sari et al., 2019). Oleh karena itu, tujuan program pengabdian masyarakat ini adalah untuk meningkatkan keterampilan guru-guru di Kota Sekayu dalam menyusun soal HOTS berbasis daring melalui kegiatan workshop.

Lebih lanjut, tujuan penulisan artikel ini adalah untuk memberikan gambaran proses pengimplementasian kegiatan pengbadian yang mampu memberikan kontribusi pada peningkatan kompetensi guru yang dibutuhkan di era Abad 21. Informasi semacam ini merupajan informasi penting yang dapat dijadikan dasar program pengbadian di dunia pendidikan. Keberadaan artikel ini juga akan berkontribusi dalam menstimulus program pengabdian yang serupa. Program pengbadian yang berfokus pada kompetensi guru memiliki signifikansi yang nyata karena berkontribusi dalam pencapaian Sustainable Development Goals (SDGs). Pemecahan berbagai permasalahan yang tertuang di 17 goals tidak terlepas dari penguasaan sains masyarakat (Marope, 2017; Queiruga-Dios et al., 2020). Tak heran, dengan peningkatan kompetensi guru maka kegiatan pengabdian semacam ini dapat berkontribusi besar dalam pencapaian 17 tujuan yang dirumuskan dalam kerangka SDGs.

\section{METODE}

Mengingat belum terampilnya guru-guru Biologi SMA di Sekayu dalam menyusun soal yang mengarah kepada HOTS, maka diperlukan adanya upaya berupa kegiatan yang dapat membekali guru untuk meningkatkan kompetensinya. Satu kegiatan yang diduga cukup efektif adalah dengan memberikan workshop penyusunan instrumen HOTS mata pelajaran IPA/Biologi. Secara keseluruhan sebagai kerangka pemecahan masalah dalam kegiatan workshop ini dapat digambarkan melalui bagan di Gambar 1. Kegiatan pengabdian ini dilaksanakan pada Bulan September 2019.

Khalayak sasaran kegiatan workshop ini adalah guru-guru Biologi SMA di Sekayu dan pemateri dan penyelenggara workshop adalah tim Program Studi Pendidikan Biologi Jurusan PMIPA FKIP Universitas Sriwijaya. Jumlah guru yang mengikuti aktif workshop ini sekitar 25 orang yang berasal dari sekolah negeri maupun swasta. Untuk menjaga efektivitas dan efisiensi kegiatan, pelaksanaan kegiatan workshop ditempuh melalui dua tahap kegiatan utama yaitu model klasikal dan kegiatan kelompok. Pada fase pertama, seluruh peserta mengerjakan tes awal terlebih dahulu. Tes ini ditujukan untuk mengetahui kemampuan awal peserta workshop dalam hal memahami soal-soal berpikir tingkat tinggi. Selanjutnya peserta mengikuti kegiatan klasikal berupa presentasi materi workshop dari tim instruktur pengabdian tentang ruang lingkup HOTS. Model penyampaian materi melalui pembelajaran langsung divariasikan dengan metode tanya jawab dan pemberian contohcontoh. Pada fase kedua, kegiatan workshop dilakukan dalam formasi kelompok. Peserta dibagi menjadi beberapa kelompok kecil yang terdiri atas 4-5 orang untuk mempraktikkan penyusunan instrumen HOTS. Setiap kelompok diberi kebebasan untuk memilih materi. Selama kegiatan kelompok, masing-masing pelatih bertindak sebagai instruktur/fasilitator, pembimbing, dan memberi petunjuk-petunjuk bila peserta workshop menemukan masalah. Pada fase ketiga, kegiatan workshop diisi dengan presentasi masing-masing peserta workshop diselingi diskusi secara klasikal. 


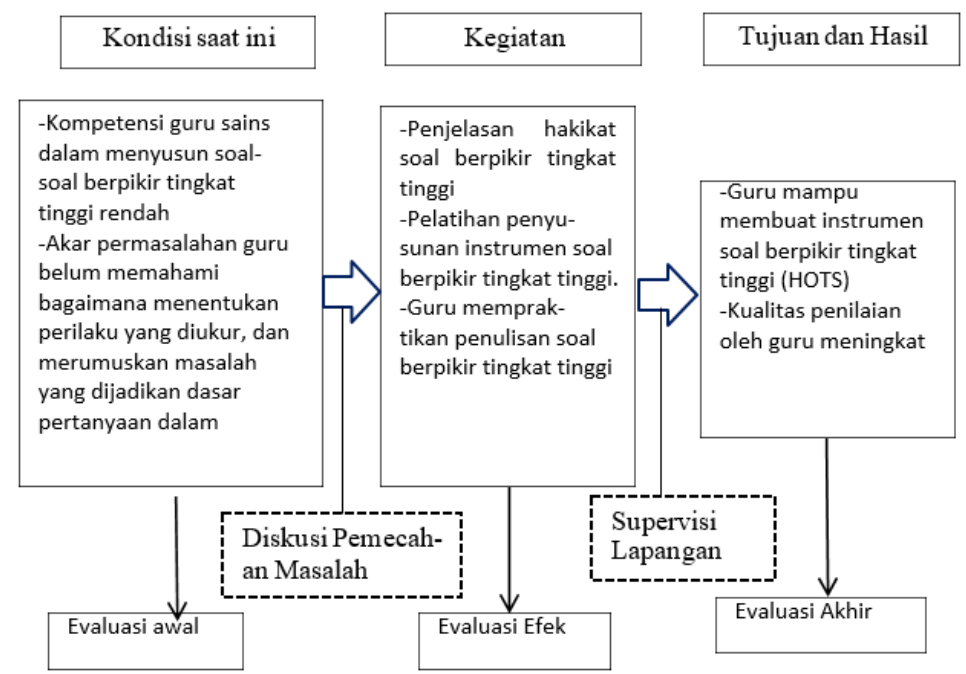

Gambar 1. Alur Kerangka Pemikiran Pemecahan Masalah dalam Kegiatan Workshop Penyusunan Soal HOTS

Untuk melihat keberhasilan kegiatan pengabdian dilakukan kegiatan evaluasi. Sebagai evaluasi awal, seluruh peserta diberikan tes awal secara tertulis yang bertujuan untuk mengetahui seberapa jauh pengetahuan dan pemahaman awal peserta dalam penguasaan konsep dan soal-soal HOTS. Evaluasi juga akan diberikan selama berlangsungnya proses workshop, antara lain melalui tes kinerja. Pada akhir kegiatan peserta akan diberikan tes akhir dalam bentuk tertulis. Untuk mengetahui tingkat keberhasilan dari workshop, hasil tes akhir akan dibandingkan dengan skor tes awal. Di samping itu, evaluasi dilakukan terhadap tugas kinerja dalam penyusunan soal-soal HOTS.

\section{HASIL DAN PEMBAHASAN}

Tahapan pertama kegiatan pengabdian masyarakat yang dilaporkan pada artikel ini adalah tahap perencanaan. Langkah awal di tahap perencanaan adalah pembentukan satuan tugas pengabdian. Pelaksanaan tahap ini didahului dengan melakukan koordinasi bersama Ketua Program Studi Pendidikan Biologi Universitas Sriwijaya. Kegiatan ini dilakukan pada bulan September 2019. Dalam pertemuan tersebut dibicarakan dan diputuskan anggota tim pengabdian, terdiri atas lima orang dosen program studi yang menjadi satuan tugas dalam pelaksanaan pengabdian periode ini ditambah satu orang mahasiswa. Pada pertemuan tersebut disepakati bahwa tim pengabdian terdiri atas satu orang ketua dan lima orang anggota yang salah satunya melibatkan mahasiswa. Adapun susunan tim pelaksana dan perannya dalam kegiatan pengabdian diputuskan seperti tertera pada Tabel 1.

Tabel 1. Susunan Tim Pelaksana Pengabdian

\begin{tabular}{lllc}
\hline No & \multicolumn{1}{c}{ Nama Dosen } & \multicolumn{1}{c}{ Materi Sajian } & Alokasi Waktu (Jam pelajaran) \\
\hline 1 & Dr. Adeng Slamet, M.Si & $\begin{array}{l}\text { Kebiasaan berpikir (Habits of Minds) } \\
\text { dalam Pembelajaran }\end{array}$ & 1 \\
3 & Dra. Siti Huzaifah, M.Sc.Ed. & $\begin{array}{l}\text { Keterampilan Berpikir Tingkat Tinggi } \\
\text { (Higher Order Thinking Skills/HOTS) }\end{array}$ & 1 \\
4 & Dr. Yenny Anwar, M.Pd & Soal HOTS berbasis daring & 1 \\
5 & Drs. Kodri Madang, M.Si. & Soal HOTS berbasis daring & 1 \\
6 & Dr. Meilinda, M.Pd & Soal HOTS berbasis daring & 1 \\
\hline
\end{tabular}

Langkah selanjutnya adalah kegiatan pembekalan tim pelaksana. Pembekalan dimaksudkan untuk menyamakan persepsi di antara tim pengabdian. Kegiatan pembekalan berlangsung melalui kegiatan diskusi dan curah pendapat di antara anggota tim. Dari kegiatan ini dihasilkan beberapa kesepakatan mencakup: 1) rancangan mekanisme kegiatan pelatihan/skenario pelatihan; 2) rincian tugas setiap anggota pelaksana; 3) pembagian tugas penyajian materi dalam pelatihan serta 4) kesepakatan beberapa hal teknis berkaitan dengan metode/teknik pelaksanaan pengabdian dengan sasaran guru IPA.

Setelah tahap perencanaan terselesaikan, kegiatan pengabdian memasukan tahapan pelaksanaan kegiatan pelatihan. Beberapa kegiatan yang dilakukan selama implementasi pelatihan terlaksana secara terarah, terencana, dan terprogram. Waktu pelaksanaan pengabdian berlangsung dalam tiga kali pertemuan dilaksanakan mulai pukul 08.00 sampai dengan 16.00 WIB, berturut-turut tanggal 3 September 2019 dan 4 September 2019.

Di awal kegiatan pelaksanaan diadakan tes awal. Pelaksanaan tes dilakukan secara individual dalam waktu 30 menit, mulai pukul 08.30 s.d 09.00. Berdasarkan hasil observasi selama kegiatan ini, tampak para peserta begitu serius dalam mengerjakan soal yang diberikan. Setelah dilakukan pengoreksian terhadap jawaban, diperoleh hasil bahwa pengetahuan 
awal mereka tentang persoalan yang dikerjakan masih termasuk kategori rendah. Hal ini ditandai dengan tidak adanya peserta pelatihan yang mendapatkan nilai di atas 60. Berpijak kepada fakta tersebut dapat dijadikan indikasi bahwa pengetahuan guru-guru IPA yang berpartisipasi dalam kegiatan pengabdian ini masih kurang.

Setelah para peserta mengikuti tes kemampuan awal pada pertemuan pertama, selanjutnya para peserta langsung mengikuti sesi paparan materi pelatihan. Pada sesi ini diisi dengan penyampaian materi oleh para pelatih selama lima jam pelajaran. Metode penyampaian materi pelatihan dilakukan dengan metode pembelajaran langsung yang divariasikan dengan tanya jawab dan diskusi informasi. Berdasarkan hasil observasi dan wawancara selama berlangsungnya sajian materi dapat diketahui bahwa seluruh peserta pelatihan tampak begitu serius dalam mengikuti penyampaian materi oleh para pelatih. Antusiasme dan rasa ingin tahu para peserta sangat tinggi dalam mengikuti sajian materi. Hal ini ditandai dengan begitu aktifnya para peserta saat dilakukan tanya jawab. Dari observasi, menunjukkan para peserta berpartisipasi aktif dalam mengikuti sajian materi. Selama proses mereka banyak mengajukan pertanyaan maupun tanggapan, sehingga suasana kelas benar-benar sangat kondusif.

Selanjutnya, diadakan kegiatan latihan dasar penyusunan soal dan pembentukan kelompok kerja. Kegiatan ini berlangsung setelah para peserta dibekali dengan wawasan pengetahuan melalui sajian materi oleh lima instruktur. Latihan dasar penyusunan soal berlangsung selama 3 jam pelajaran di bawah bimbingan para instruktur. Pada latihan ini para peserta diberi kebebasan memilih materi IPA untuk bahan penyusunan soal. Selanjutnya, di antara peserta diminta untuk menayangkan contoh soal yang selesai dibuat dan dilakukan pembahasan serta diskusi.

Pada akhir pertemuan pertama, para peserta dibagi menjadi beberapa kelompok kerja berdasarkan jenjang materi IPA di SMA. Kelompok kerja yang dibentuk terdiri atas tiga kelompok besar yaitu kelompok yang mengerjakan soal-soal HOTS kelas VII, VIII, dan IX. Agar para peserta bekerja efektif dan fokus, maka pada setiap kelompok dibagi lagi menjadi dua kelompok lebih kecil. Setelah itu, kegiatan yang dilakukan adalah praktik penyusunan soal.

Kegiatan praktik penyusunan soal HOTS dalam kegiatan pengabdian ini berlangsung pada pertemuan ke dua yaitu pada hari Senin, 2 September 2019 mulai pukul 09.00 s.d. 16.00. Dalam sesi ini para peserta bekerja dalam formasi kelompok sesuai dengan pembagian kelompok yang dibentuk pada pertemuan pertama. Saat berlangsungnya praktik penyusunan soal HOTS, setiap kelompok didampingi oleh para instruktur. Jumlah soal yang disusun masing-masing kelompok minimal lima butir/item soal mencakup lima topik berbeda. Ragam soal yang disusun peserta diarahkan dan harus berorientasi kepada tipe soal model PISA (Programme International for Student Assessment). Setelah setiap kelompok menyusun soal, dilanjutkan dengan membuatnya di dalam google form agar bisa diakses oleh siswa.

Dalam kegiatan praktik penyusunan soal, para pelatih berperan sebagai fasilitator. Luaran dari sesi ini para peserta harus menghasilkan produk berupa soal-soal HOTS yang ditautkan ke google form. Berpijak kepada target yang ditetapkan dari kegiatan ini dapat diketahui bahwa ternyata para peserta pelaithan belum berhasil menyelesaikan jumlah butir soal HOTS untuk kelas X, XI, dan XII mata pelajaran SMA sesuai dengan jumlah butir soal yang ditentukan. Oleh karena itu, setiap kelompok ditugaskan untuk mengerjakannya di rumah masing-masing. Setiap kelompok diberi waktu paling lambat dua minggu (sampai dengan tanggal 10 Oktober 2019) untuk menyelesaikan produknya (butir soal HOTS), dan mengirimkannya ke alamat surat elektronik (surel) panitia.

Kegiatan terakhir adalah presentasi hasil penyusunan soal HOTS. Kegiatan presentasi dilakukan pada hari Selasa, tanggal 4 September 2019 mulai pukul 08.00 sampai dengan pukul 12.00 di SMA Negeri 2 Sekayu. Adanya format presentasi dalam kegiatan pelatihan ini dimaksudkan untuk mendiseminasikan produk berupa butir-butir soal HOTS yag disusun setiap kelompok kepada seluruh peserta pelatihan. Setelah kegiatan presentasi, aktivitas selanjutnya adalah diskusi dan tanya jawab. Berdasarkan hasil observasi dalam sesi ini, tampak suasana presentasi dan diskusi berlangsung dalam suasana yang menyenangkan dan kondusif. Interaksi dalam diskusi terjadi dalam berbagai arah baik antara peserta dengan instruktur maupun antar peserta dengan peserta. Berdasarkan masukan dan saran-saran dari peserta, setiap kelompok diberi kesempatan untuk memperbaiki butir soalnya. Setelah dilakukan beberapa revisi pada setiap kelompok, dihasilkan sebuah dokumen soal HOTS yang tertaut dengan google form. Masing-masing peserta dapat mengakses soalsoal dengan mengakses tautan dari masing-masing kelompok. Selain itu, dokumen soal yang dikumpulkan seluruhnya dibagikan kepada seluruh peserta dan dikirimkan ke surel masing-masing peserta pelatihan.

Peningkatan kompetensi guru dalam menyusun soal HOTS merupakan kegiatan yang penting dilakukan secara berkelanjutan. Alasannya, soal HOTS menjadi alat evaluasi yang harus digunakan guru untuk mengukur keberhasilan pembelajarannya (Ramdiah et al., 2019). Pembelajaran saat ini harus mampu memberdayakan HOTS siswa (Ghanizadeh, 2017; Miri et al., 2007; Pratama \& Retnawati, 2018) sehingga alat ukur keberhasilan belajar juga harus berbasis HOTS (Abosalem, 2015; Andromeda et al., 2020; Ramdiah et al., 2019). Dengan menggunakan alat evaluasi berupa soal-soal HOTS maka guru dapat memastikan apakah siswanya telah siap menghadapi dunia nyata setelah lulus kelak. Pernyataan ini didasarkan pada persaingan dunia kerja yang semakin ketat. Pelamar yang dibekali dengan HOTS akan berpeluang lebih besar untuk dapat bersaing di dunia kerja. Selain itu, HOTS juga penting bagi setiap individu dalam menelaah informasi yang mereka dapat. Mereka dapat secara kritis mengevaluasi informasi tersebut dan secara kreatif memanfaatkan peluang dari informasi yang mereka dapat (Dwyer et al., 2014; Glaze, 2018; Santika et al., 2018; Sellars et al., 2018).

Selain menekankan pada HOTS, kegiatan pengabdian yang dilaporkan pada artikel ini juga ditekankan pada pengalaman guru menyusun soal evaluasi berbasis daring. Kegiatan evaluasi berbasis daring perlu dikuasai oleh guru karena di era digital saat ini guru juga harus memiliki keterampilan digital (Falloon, 2020; Garzón Artacho et al., 2020) 
Keterampilan digital tersebut harus diimplementasikan ke kegiatan belajar mengajar, baik dalam proses penyampaian ilmu maupun proses evaluasi pembelajaran. Kegiatan pembelajaran berbasis digital juga akan mendorong siswa untuk lebih terbiasa menggunakan aplikasi digital. Keterampilan serta literasi digital juga dianggap sebagai modal utama siswa menghadapi perkembangan dunia yang pesat ini (Breakstone et al., 2018; Leahy \& Dolan, 2010; Spires et al., 2019). Oleh karena itu, guru seharusnya dapat beradaptasi dengan perkembangan dunia dan mampu secara optimal memanfaatkan perkembangan dunia digital dalam penyelenggaraan pembelajaran.

\section{KESIMPULAN}

Dari kegiatan pengabdian pada masyarakat ini dapat disimpulkan bahwa ada peningkatan pengetahuan dan keterampilan para guru SMA dalam merancang dan membuat alat evaluasi untuk mengukur HOTS siswa. Selain itu, kegiatan pengabdian ini menghasilkan dokumen soal HOTS berbasis daring untuk mata pelajaran SMA. Didasarkan pada hasil positif kegiatan pengabdian masyarakat ini, pelatihan serupa diharapkan juga diadakan di daerah lain. Selain iti, diharapkan pula adanya kesinambungan dan monitoring pasca kegiatan pengabdian. Dengan demikian, guru-guru SMA dapat mempraktikan pembuatan soal yang berorientasi pada kemampuan berpikir tingkat dalam praktik pembelajaran di sekolah dan memanfaatkan tekhnologi untuk lebih praktis.

\section{REFERENSI}

Abosalem, Y. (2015). Assessment techniques and students' higher-order thinking skills. ICSIT 2018 - 9th International Conference on Society and Information Technologies, Proceedings, 4(1), 61-66. https://doi.org/10.11648/j.ijsedu.20160401.11

Alruwais, N., Wills, G., \& Wald, M. (2018). Advantages and challenges of using e-assessment. International Journal of Information and Education Technology, 8(1), 34-37. https://doi.org/10.18178/ijiet.2018.8.1.1008

Andromeda, A., Fitriza, Z., \& 'Aini, F. Q. (2020). Evaluation of pedagogy competence of chemistry teacher in compiling Higher Order Thinking Skill (HOTS) assessment instrument for high school students. Edukimia, 2(2), 91-95. https://doi.org/10.24036/ekj.v2.i2.a134

Anif, S., Sutama, S., Prayitno, H. J., \& Idrus, N. B. M. (2019). Effectiveness of pedagogical competence: A development model through association of biology teachers' forum. Jurnal Pendidikan IPA Indonesia, 8(1), 22-31. https://doi.org/10.15294/jpii.v8i1.17176

Baran, E., Correia, A.-P., \& Thompson, A. (2011). Transforming online teaching practice: critical analysis of the literature on the roles and competencies of online teachers. Distance Education, 32(3), 421-439. https://doi.org/10.1080/01587919.2011.610293

Behar-Horenstein, L. S., \& Niu, L. (2011). Teaching critical thinking skills in higher education: A review of the literature. Journal of College Teaching \& Learning (TLC), 8(2), 25-42. https://doi.org/10.19030/tlc.v8i2.3554

Breakstone, J., McGrew, S., Smith, M., Ortega, T., \& Wineburg, S. (2018). Why we need a new approach to teaching digital literacy. Phi Delta Kappan, 99(6), 27-32. https://doi.org/10.1177/0031721718762419

Dwyer, C. P., Hogan, M. J., \& Stewart, I. (2014). An integrated critical thinking framework for the 21st century. Thinking Skills and Creativity, 12, 43-52. https://doi.org/10.1016/j.tsc.2013.12.004

Epinasti, G., Slamet, S. T. Y., \& Yamtinah, S. (2013). Elementary teacher profile about assessment of Higher Order Thinking Skills ( HOTS ) in 2013 Curriculum. 5th ICRIEMS Proceedings, 25-30.

http://seminar.uny.ac.id/icriems/sites/seminar.uny.ac.id.icriems/files/proceeding2018/SE04_GUNANING EPINASTI.pdf

Falloon, G. (2020). From digital literacy to digital competence: the teacher digital competency (TDC) framework. Educational Technology Research and Development, 68(5), 2449-2472. https://doi.org/10.1007/s11423-02009767-4

Frankl, G., \& Bitter, S. (2012). Online exams: Practical implications and future directions. 11th European Conference on E-Learning, October 2012, 158-165. https://doi.org/10.1017/CBO9781107415324.004

Garzón Artacho, E., Martínez, T. S., Ortega Martín, J. L., Marín Marín, J. A., \& Gómez García, G. (2020). Teacher training in lifelong learning-The importance of digital competence in the encouragement of teaching innovation. Sustainability, 12(7), 2852. https://doi.org/10.3390/su12072852

Ghanizadeh, A. (2017). The interplay between reflective thinking, critical thinking, self-monitoring, and academic achievement in higher education. Higher Education, 74(1), 101-114. https://doi.org/10.1007/s10734-016-0031-y

Glaze, A. (2018). Teaching and learning science in the 21st century: Challenging critical assumptions in post-secondary science. Education Sciences, 8(1), 12. https://doi.org/10.3390/educsci8010012

Greiff, S., Niepel, C., \& Wüstenberg, S. (2015). 21st century skills: International advancements and recent developments. Thinking Skills and Creativity, 18, 1-3. https://doi.org/10.1016/j.tsc.2015.04.007

Irmawati, D., Widiati, U., \& Cahyono, B. (2017). How do Indonesian professional English teachers develop their pedagogical competence in teaching implementation? Arab World English Journal, 8(2), 293-307. 
https://doi.org/10.24093/awej/vol8no2.21

Leahy, D., \& Dolan, D. (2010). Digital literacy: A vital competence for 2010? In Key Competencies in the Knowledge Society. KCKS 2010. IFIP Advances in Information and Communication Technology (pp. 210-221). Springer. https://doi.org/10.1007/978-3-642-15378-5_21

Mantra, I. B. N., Astawa, I. N., \& Rustini, N. K. P. (2019). Fostering teachers' professional competence through intensive collaborative workshop in cyclic learning systems. Lingua Scientia, 26(2), 90-94. https://ejournal.undiksha.ac.id/index.php/JJBI/article/download/22466/14019

Marope, P. T. M. (2017). Literacy: A foundation for achieving the Sustainable Development Goals. PROSPECTS, 47(3), 163-165. https://doi.org/10.1007/s11125-018-9436-y

McKnight, K., O’Malley, K., Ruzic, R., Horsley, M. K., Franey, J. J., \& Bassett, K. (2016). Teaching in a digital age: How educators use technology to improve student learning. Journal of Research on Technology in Education, 48(3), 194-211. https://doi.org/10.1080/15391523.2016.1175856

Miri, B., David, B.-C., \& Uri, Z. (2007). Purposely teaching for the promotion of higher-order thinking skills: A case of critical thinking. Research in Science Education, 37(4), 353-369. https://doi.org/10.1007/s11165-006-9029-2

Montag-Smit, T., \& Maertz, C. P. (2017). Searching outside the box in creative problem solving: The role of creative thinking skills and domain knowledge. Journal of Business Research, 81, 1-10. https://doi.org/10.1016/j.jbusres.2017.07.021

Mulnix, J. W. (2012). Thinking critically about critical thinking. Educational Philosophy and Theory, 44(5), 464-479. https://doi.org/10.1111/j.1469-5812.2010.00673.x

Ottenbreit-Leftwich, A. T., Brush, T. A., Strycker, J., Gronseth, S., Roman, T., Abaci, S., VanLeusen, P., Shin, S., Easterling, W., \& Plucker, J. (2012). Preparation versus practice: How do teacher education programs and practicing teachers align in their use of technology to support teaching and learning? Computers \& Education, 59(2), 399-411. https://doi.org/10.1016/j.compedu.2012.01.014

Ottenbreit-Leftwich, A. T., Glazewski, K. D., Newby, T. J., \& Ertmer, P. A. (2010). Teacher value beliefs associated with using technology: Addressing professional and student needs. Computers \& Education, 55(3), 1321-1335. https://doi.org/10.1016/j.compedu.2010.06.002

Pratama, G. S., \& Retnawati, H. (2018). Urgency of Higher Order Thinking Skills (HOTS) Content Analysis in Mathematics Textbook. Journal of Physics: Conference Series, 1097(1). https://doi.org/10.1088/1742-6596/1097/1/012147

Purwoko, A. A., Andayani, Y., Muntar, M., \& Diartha, I. N. (2017). Efforts in improving teachers' competencies through collaboration between teacher forum on subject matter (MGMP) and pre-service teacher training institution (LPTK). Jurnal Pendidikan IPA Indonesia, 6(1), 11-15. https://doi.org/10.15294/jpii.v6i1.8858

Queiruga-Dios, M. Á., López-Iñesta, E., Diez-Ojeda, M., Sáiz-Manzanares, M. C., \& Dorrío, J. B. V. (2020). Citizen science for scientific literacy and the attainment of sustainable development goals in formal education. Sustainability (Switzerland), 12(10), 1-18. https://doi.org/10.3390/su12104283

Ramdiah, S., Abidinsyah, Royani, M., \& Husamah. (2019). Understanding, planning, and implementation of HOTS by senior high school biology teachers in Banjarmasin-Indonesia. International Journal of Instruction, 12(1).

Retnawati, H., Djidu, H., Kartianom, K., Apino, E., \& Anazifa, R. D. (2018). Teachers' knowledge about higher-order thinking skills and its learning strategy. Problems of Education in the 21st Century, 76(2), 215-230. https://doi.org/10.33225/pec/18.76.215

Saavedra, A. R., \& Opfer, V. D. (2012). Learning 21st-Century skills requires 21st-Century teaching. Phi Delta Kappan, 94(2), 8-13. https://doi.org/10.1177/003172171209400203

Santika, A. R., Purwianingsih, W., \& Nuraeni, E. (2018). Analysis of students critical thinking skills in socio-scientific issues of biodiversity subject. Journal of Physics: Conference Series, 1013(1). https://doi.org/10.1088/1742$6596 / 1013 / 1 / 012004$

Sari, V. F., Afriyenti, M., Arza, F. I., \& Setiawan, M. A. (2019). Improving vocational teachers' readiness in teaching new subject "Accounting practice of the institution and local government agencies." Proceedings of the 2nd Padang International Conference on Education, Economics, Business and Accounting (PICEEBA-2 2018), 64, 36-42. https://doi.org/10.2991/piceeba2-18.2019.5

Sellars, M., Fakirmohammad, R., Bui, L., Fishetti, J., Niyozov, S., Reynolds, R., Thapliyal, N., Liu-Smith, Y. L., \& Ali, N. (2018). Conversations on critical thinking: Can critical thinking find its way forward as the skill set and mindset of the century? Education Sciences, 8(4). https://doi.org/10.3390/educsci8040205

Spires, H. A., Medlock Paul, C., \& Kerkhoff, S. N. (2019). Digital literacy for the 21st Century. In M. Khosrow-Pour (Ed.), Encyclopedia of Information Science and Technology (Fourth Edi, Issue January, pp. 12-21). IGI Global. https://doi.org/10.4018/978-1-5225-7659-4.ch002 